\title{
ESR and Optical Studies on the Interaction between $\mathrm{Cu}(\mathrm{II})$ and Pepsin
}

\author{
L. Sportelli * ${ }^{*}$ H. Neubacher, and W. Lohmann \\ Institut für Biophysik, Strahlenzentrum der Justus Liebig-Universität Gießen \\ Z. Naturforsch. 33 c, $321-325$ (1978) ; received March 10, 1978 \\ $\mathrm{Cu}$ (II) -Complexes, Pepsin, ESR, Optical Absorption \\ The interaction of $\mathrm{Cu}(\mathrm{II})$ with the protein pepsin has been investigated by means of electron \\ spin resonance (ESR) and optical spectroscopy. Depending on the molar ratio of $\mathrm{Cu}$ (II) and \\ pepsin in aqueous solution two different complexes are formed. A third complex can be detected \\ after a reaction time of several days, attributed to a complex with a conformationally changed \\ pepsin. The presence of inhibitors 1,2-epoxy-3-phenoxypropane (EPP) or diazoacetyl-ethylester \\ (DAE) seems to hinder the conformational change. The structure of the three complexes is \\ discussed.
}

\section{Introduction}

It is well established that the proteolytic enzyme pepsin undergoes total inhibition by epoxy and diazo compounds $[1-6]$. The epoxy inhibitors modify chemically Asp-32 whereas the diazo inhibitors modify Asp-215. Both of these aspartic acids are in the active center of the enzyme and are important for its enzymatic activity. Measurements from different laboratories have shown that the inhibition of pepsin by diazo substances is increased considerably if $\mathrm{Cu}(\mathrm{II})$ ions are present in the reagent mixture $[4,5,7-10]$.

Lundblad and Stein [9] and Stein [10] have proposed the formation of an intermediate reactive $\mathrm{Cu}$ (II)-carbene complex during the inhibition process. Since the cupric ion is paramagnetic, it is possible to study the interaction between the components of the system pepsin/Cu(II) as well as of the ternary system pepsin/inhibitor/Cu(II) by means of electron spin resonance (ESR) technique.

In this communication we report the findings of these studies which suggest that pepsin coordinates to $\mathrm{Cu}(\mathrm{II})$ via two oxygen and two nitrogen atoms. The geometry of the complex is approximately square planar with the ligand atoms located at the corners of the square. A conformational change of the protein determines the complex formation which is influenced, moreover, by temperature and inhibitor.

\section{Material and Methods}

Hog pepsin (EC 3.4.4.1), 2-fold crystallized, was a commercial product purchased from Serva (Hei-

* Part of the Ph.D. of L. S., D-26.

- Present address: Istituto Superiore di Sanitá, Rome, Italy.

Requests for reprints should be sent to Dr. H. Neubacher, Institut für Biophysik, Strahlenzentrum der Justus LiebigUniversität Gießen, Leihgesterner Weg 217, D-6300 Gießen. delberg, Germany) and was used without further purification. $\mathrm{Cu}\left(\mathrm{NO}_{3}\right)_{2} \cdot 3 \mathrm{H}_{2} \mathrm{O}$ was obtained from Merck (Darmstadt, Germany) whereas the pepsin inhibitors 1,2-epoxy-3-phenoxypropane (EPP) and diazoacetylethylester (DAE) were purchased from either Riedel-DeHaën (Hannover, Germany), or Roth (Karlsruhe, Germany).

The solutions were prepared in double destilled water. All binary systems were mixed for $2 \mathrm{~h}$ at $37^{\circ} \mathrm{C}$ before performing the measurements. The ternary systems were prepared by adding a $\mathrm{Cu}$ (II) solution to a pepsin-inhibitor solution.

The ESR spectra of the $\mathrm{Cu}$ (II) -pepsin complexes were recorded with an X-band Varian E-9 spectrometer using $100 \mathrm{kC}$ field modulation. The microwave power was $10 \mathrm{~mW}$ for all samples investigated and the modulation amplitude $2 \mathrm{G}$ if not indicated otherwise. The optical measurements were done with a Zeiss DMR 10 spectrophotometer. The $\mathrm{pH}$ value of the solutions was measured with a Knick precision $\mathrm{pH}$-meter with an $\mathrm{Ag} / \mathrm{AgCl}$ electrode. The timedependent studies were performed on samples stored at $22{ }^{\circ} \mathrm{C}$ (room temperature, RT).

\section{Results}

ESR spectra of Cu(II)-pepsin complexes. An aqueous $1 \mathrm{~mm} \mathrm{Cu(II)}$ solution has been mixed with different pepsin concentrations of up to $800 \mu \mathrm{M}$. The ESR spectra obtained at RT (Fig. 1, A-C) and $77 \mathrm{~K}$ (Fig. 2, A-C) have been recorded.

As can be seen, the solutions containing $80 \mu \mathrm{M}$ and $160 \mu \mathrm{M}$ pepsin, resp., exhibit, at room temperature, ESR spectra with no well resolved $\mathrm{Cu}$ (II) hyperfine (hf)-structure (Fig. 1, A, B). At concentrations above $320 \mu \mathrm{M}$ of pepsin (s. Fig. 1 C) the 

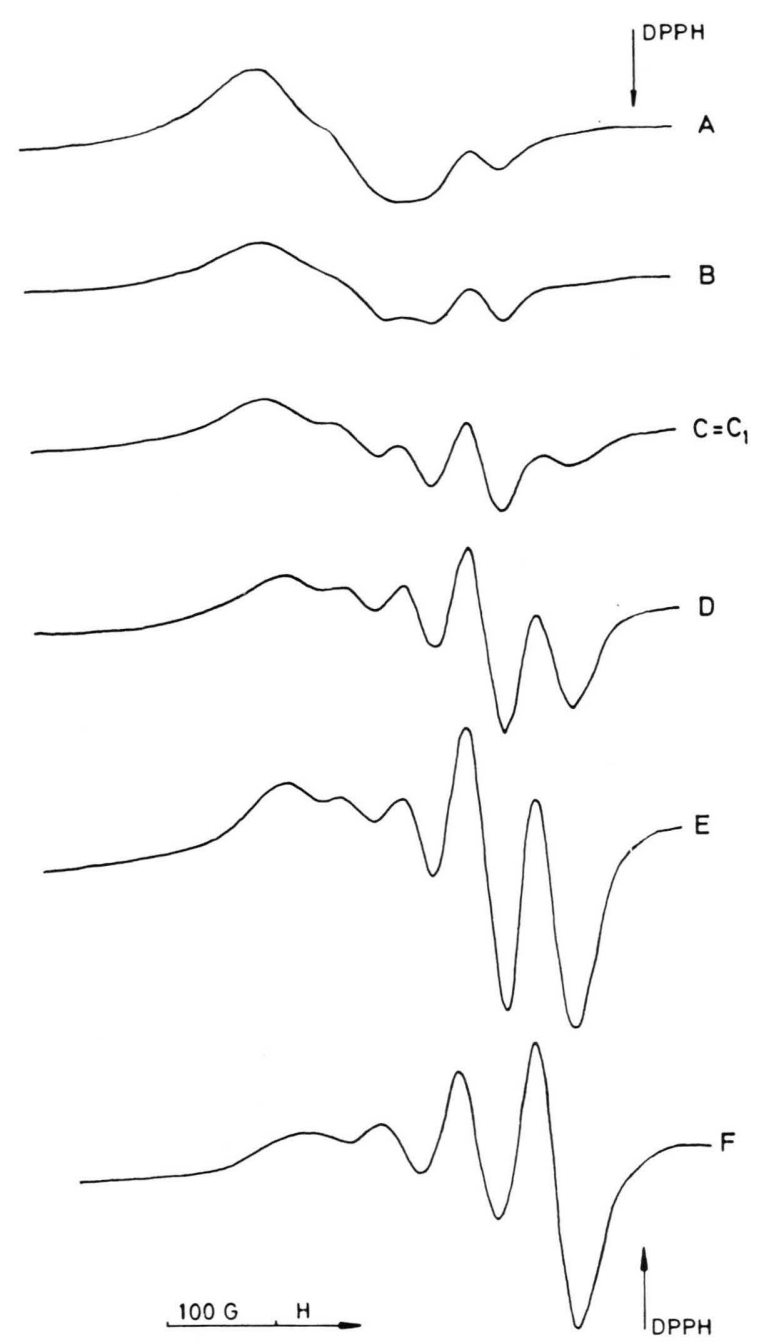

Fig. 1. ESR spectra of aqueous solutions of $\mathrm{Cu}(\mathrm{II}), 1 \mathrm{~mm}$, recorded at $\mathrm{RT}$ in the presence of different pepsin concentrations $\mathrm{A}, \mathrm{B}, \mathrm{C}, \mathrm{C}_{1}$ and various storage times $\mathrm{D}, \mathrm{E}, \mathrm{F}$. A: $80 \mu \mathrm{M}$ pepsin; B: $160 \mu \mathrm{M}$ pepsin; C: $320 \mu \mathrm{M}$ pepsin, $\mathrm{C}_{1}$ : $800 \mu \mathrm{M}$ pesin; samples measured after $2 \mathrm{~h}$ storage at $37^{\circ} \mathrm{C}$. $\mathrm{D}, \mathrm{E}$, and F: $800 \mu \mathrm{M}$ pepsin solutions measured after 4, 8, and 12 days storage at RT. hf-structure as well as an additional line in the high field region of the spectrum can be observed.

Some more detailed information can be obtained by the ESR spectra recorded at $77 \mathrm{~K}$. The low field side of the $\mathrm{Cu}$ (II) signal of the solution containing $320 \mu \mathrm{M}$ of the enzyme seems to exist of two quartets belonging to two different $\mathrm{Cu}(\mathrm{II})$ pepsin complexes (Fig. $2 \mathrm{C}$ ). The magnetic parameters $\left|A_{\|}\right|$and $g_{\|}$of both of the complexes are reported in Table I. An increase in the enzyme concentration results in the domination of one complex (Fig. $2 \mathrm{C}_{1}$ ).

Furthermore, a prolonged storage time will result in the final $\mathrm{Cu}(\mathrm{II})$-pepsin complex with the hf structure shown in Figs $1 \mathrm{~F}$ and $2 \mathrm{~F}$.

The optical absorption spectra of the $\mathrm{Cu}(\mathrm{II})$ pepsin solutions are shown in Fig. 3. A shift of the maximum of the $\mathrm{Cu}$ (II) d-d absorption band towards shorter wavelengths with increasing enzyme concentrations can be seen in the insert of Fig. 3 . Those solutions had been mixed for two hours only. A prolonged storing over 8 days results in a new absorption band at about $520 \mathrm{~nm}$ which, again, might resemble the final complex.

ESR spectra of Cu(II)/inhibitor/pepsin complexes. ESR spectra of the ternary system pepsin/inhibitor/ $\mathrm{Cu}$ (II) with a molar ratio of $1: 20: 1$, at $77 \mathrm{~K}$, are shown in Fig. 4.

Fig. $4 \mathrm{~A}$ shows the ESR spectrum of the ternary system pepsin/EPP/Cu(II). As can be seen, the spectrum is composed of the superposition of two $\mathrm{Cu}$ (II) complexes with the magnetic parameters given in Table II. The spectrum does not change either with time or by an increase of $\mathrm{Cu}$ (II) up to a 10 -fold molar excess. If, however, diazoacetylethylester (DAE) is used as an inhibitor, the ESR spectrum changes with time (Fig. 4 B, C, and D). The ESR spectrum of such a solution which was

Table I. ESR parameters and maxima of the optical d-d transitions of Cu(II)-pepsin complexes as function of the enzyme concentration as well as of the storing time. The samples were mixed for $2 \mathrm{~h}$, at $37^{\circ} \mathrm{C}$, before performing the measurements and stored at room temperature, in a few cases, for 4 to 12 days. Measuring temperature $77 \mathrm{~K}$.

\begin{tabular}{|c|c|c|c|c|c|c|c|c|}
\hline $\begin{array}{l}\text { Pepsin }+ \\
(\mathrm{X} \mu \mathrm{m})\end{array}$ & $\begin{array}{l}\mathrm{Cu}(\mathrm{II}) \\
(1 \mathrm{mM})\end{array}$ & $\begin{array}{l}\left|A_{*}^{1}\right| \\
\pm 2 \text { Gauss }\end{array}$ & $\begin{array}{l}\left|A_{\|}^{2}\right| \\
\pm 2 \text { Gauss }\end{array}$ & $\begin{array}{l}\left|A_{*}^{3}\right| \\
\pm 2 \text { Gauss }\end{array}$ & $\begin{array}{l}g_{*}^{1} \\
\pm 0.002\end{array}$ & $\begin{array}{l}g_{1 "}^{2} \\
\pm 0.002\end{array}$ & $\begin{array}{l}g^{3} \\
\pm 0.002\end{array}$ & $\begin{array}{l}\lambda \\
{[\mathrm{nm}]}\end{array}$ \\
\hline $\mathrm{X}$ & time & \multirow{6}{*}{132} & & & \multirow{6}{*}{2.350} & & & \multirow{6}{*}{$\begin{array}{l}720 \pm 3 \\
654 \pm 3 \text { and } 524 \pm 3 \\
700 \pm 3 \\
\sim 650(\mathrm{~s}) \text { and } 520 \pm 3 \\
\quad(\bigcirc)\end{array}$} \\
\hline 320 & $2 \mathrm{~h}$ & & 157 & & & 2.298 & & \\
\hline 320 & 8 days & & 152 & 172 & & 2.295 & 2.247 & \\
\hline $800 *$ & $2 \mathrm{~h}$ & & 157 & & & 2.297 & & \\
\hline 800 & 8 days & & 156 & 172 & & 2.295 & 2.251 & \\
\hline 800 & 12 days & & & 172 & & & 2.247 & \\
\hline
\end{tabular}

* Magnetic parameters of the predominant $\mathrm{Cu}(\mathrm{II})$-pepsin complex. (s), Shoulder.

(O), Not recorded because of turbidity of solution. 


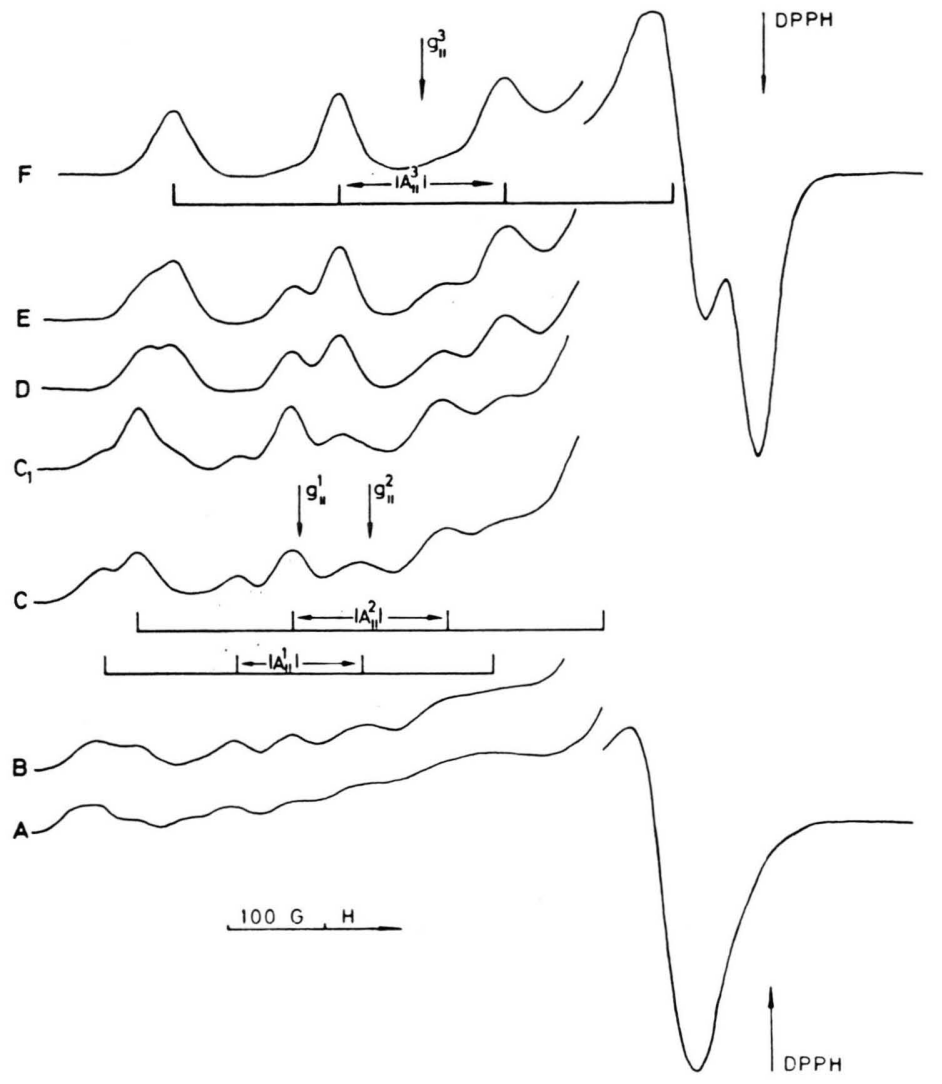

Fig. 2. ESR spectra of aqueous solutions of $\mathrm{Cu}(\mathrm{II}), 1 \mathrm{~mm}, 77 \mathrm{~K}$, in the presence of different pepsin concentrations $\mathrm{A}, \mathrm{B}, \mathrm{C}, \mathrm{C}_{1}$ and various storage times $\mathrm{D}, \mathrm{E}, \mathrm{F}$ (for explanation see Fig. 1) (amplification at the low field region $\times 2.5$, modulation amplitude $4 \mathrm{G}$ ).

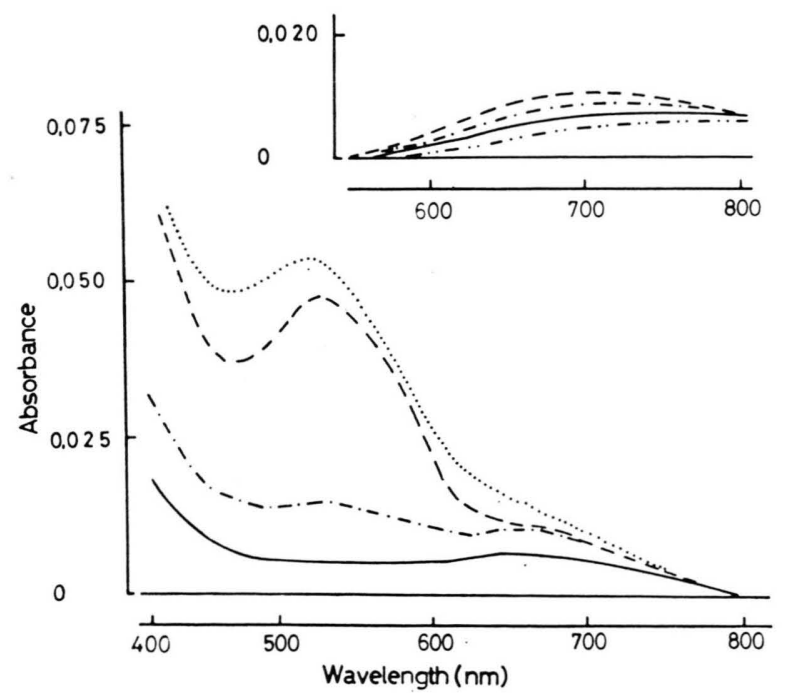

Fig. 3. Optical absorption spectra of aqueous solutions of $\mathrm{Cu}(\mathrm{II}), \mathrm{lmM}$, in the presence of different pepsin concentrations and after 8 days storage at RT: (-) $160 \mu \mathrm{M}$; $(-\cdot-\cdot-) \quad 320 \mu \mathrm{M}$ pepsin; (- - ) $640 \mu \mathrm{M}$ pepsin; $(\cdots \cdots) 800 \mu \mathrm{m}$ pepsin. Insert: $2 \mathrm{~h}$ after storage at $37^{\circ} \mathrm{C}$. $(-\cdots-\cdots-) \quad 80 \mu \mathrm{M}$ pepsin; (—) $160 \mu \mathrm{M}$ pepsin; $(-\cdot-\cdot-) 320 \mu \mathrm{M}$ pepsin; (- - ) $640 \mu \mathrm{M}$ and $800 \mu \mathrm{M}$ pepsin. stored 12 days at RT and measured at $77 \mathrm{~K}$ exhibits the hf structure of one Cu(II)-complex only (s. Fig. 4D). The magnetic parameters and the absorption maxima are given in Table II.

It should be pointed out that a spectrum with the magnetic parameters $\left|A_{\|}\right|=150 \mathrm{G}$ and $g_{\|}=2.320$ will be obtained when $\mathrm{Cu}(\mathrm{II})$ and DAE are mixed first. Addition of pepsin results in a spectrum shown in Fig. $4 \mathrm{~B}$.

Addition of $\mathrm{Cu}(\mathrm{II})$ to a pepsin solution containing both inhibitors EPP and DAE, results in an ESR spectrum very similar to that one shown in Fig. 4 A. Again, no change with time can be observed.

\section{Discussion}

As can be seen from the ESR spectra in Figs 1 and 2 different complexes are formed in aqueous $\mathrm{Cu}(\mathrm{II})$ solutions containing different pepsin concentration. Considering the ESR theory on copper complexes $[11-13]$, suggestions on the nature of the ligands and on the symmetry of the complexes can be made. 
Two kinds of complexes are present for all pepsin concentrations. The first one (complex I) has a splitting parameter $\left|A_{\|}{ }^{1}\right|=132 \mathrm{G}$ and a $g$-value $g_{\|}{ }^{1}$ $=2.350$, while the second one (complex II), which is predominant at higher pepsin concentrations, has $\left|A_{\|}{ }^{2}\right|=157 \mathrm{G}$ and $g_{\|}{ }^{2}=2.298$ (s. Table I).

$\mathrm{Cu}$ (II) -complexes which have oxygen as well as nitrogen atoms as ligands exhibit, usually, larger

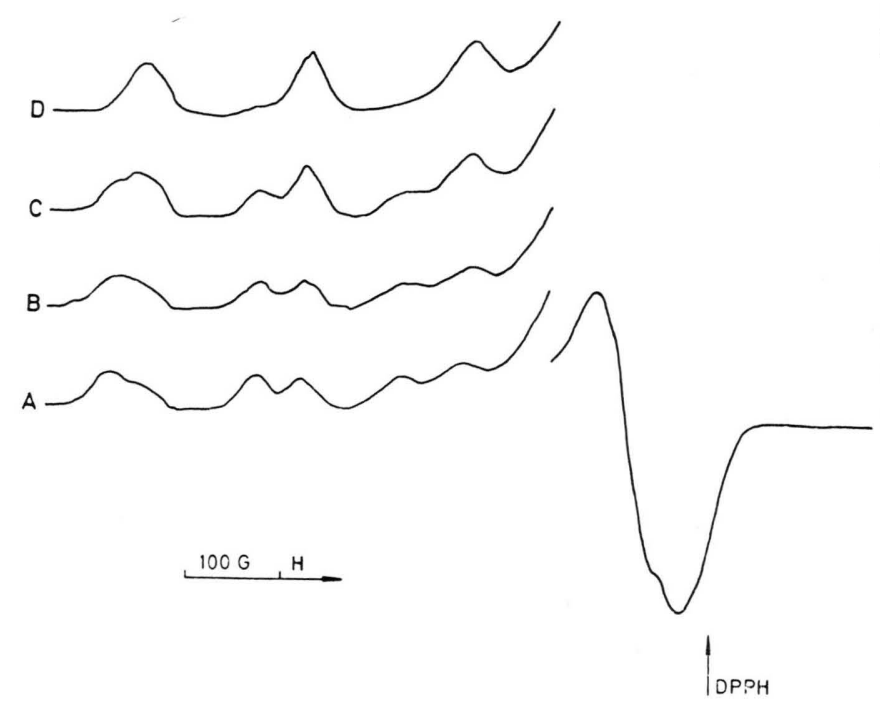

Fig. 4. Time-dependent ESR spectra $(77 \mathrm{~K})$ of the ternary system pepsin/inhibitor/Cu(II) with a molar ratio of $1: 20: 1$. $\mathrm{Cu}$ (II) concentration was kept constant at $0.5 \mathrm{~mm}$. A: obtained with EPP as an inhibitor; spectrum recorded after $2 \mathrm{~h}$ storage at $37^{\circ} \mathrm{C}$; a similar spectrum was also obtained after 12 days storage at RT. B, C, and D: obtained with $\mathrm{DAE}$ as an inhibitor; B: spectrum obtained after $2 \mathrm{~h}$ storage at $37^{\circ} \mathrm{C}$; C and $\mathrm{D}$ : spectra recorded after 6 and 12 days storage at RT. The quaternary system pepsin/EPP/ $\mathrm{DAE} / \mathrm{Cu}(\mathrm{II})$ exhibits a similar spectrum to $\mathrm{A}$ when stored either for $2 \mathrm{~h}$ at $37^{\circ} \mathrm{C}$ or for 12 days at RT after mixing (amplification at the low field region $\mathrm{x} 2.5$, modulation amplitude $4 \mathrm{G}$ ). splitting parameters $\left|A_{\|}\right|$and smaller $g_{\| \text {-values }}$ than has been observed for complex II. Therefore, it is suggested, that in either complex I and II one or two deprotonated carboxyl groups of pepsin contribute to the complex formation. Such a complex should be nearly square planar since $g_{\|}>g_{\perp}>2$ was measured for all spectra.

If $\mathrm{Cu}$ (II)-pepsin solutions are stored at room temperature for several days (s. Fig. I D, E, F, and Table I), a third type of complex (complex III) between $\mathrm{Cu}$ (II) and pepsin is formed with $\left|A_{\|}^{3}\right|=$ $172 \mathrm{G}$ and $g_{\|}{ }^{3}=2.245$. The splitting parameter and the $g$-values of this complex are about the same as for $\mathrm{Cu}(\mathrm{II})$ complexes formed with amino acids $[14,15]$. Therefore, two oxygen and nitrogen atoms each might be the ligands of the $\mathrm{Cu}$ (II) ion.

The complex III is formed probably by a change of the conformation of pepsin. The $d$-d absorption maximum of this complex (s. Fig. 3) is relatively strong $\left(\varepsilon=210 \mathrm{M}^{-1} \mathrm{~cm}^{-1}\right)$ and shifted to a shorter wavelength $(520 \mathrm{~nm})$. A d-d transition at about this wavelength was already observed for peptide complexes formed with $\mathrm{Cu}(\mathrm{II})[16,17]$. It has been attributed to a complex in which, at least, one axial position of the metal ion is occupied by a ligand atom which belongs to the peptide.

According to this it is suggested in the case of pepsin, that due to the change in the conformation also axial ligand positions of $\mathrm{Cu}(\mathrm{II})$ are occupied by atoms of the pepsin molecule.

It should be mentioned, that the complex described cannot be formed with a denatured pepsin molecule. At $\mathrm{pH}$ 9.5, when pepsin is denatured, a completely different complex is formed (not shown here).

The presence of an inhibitor of pepsin causes a certain difference in the complexation behaviour of

Table II. ESR parameters and maxima of the optical d-d transitions of pepsin/Cu(II)/inhibitor(s) systems as function of the storing time. Pepsin, $0.5 \mathrm{~mm}$; Cu(II) $0.5 \mathrm{~mm}$; EPP a and DAE b, $5 \mathrm{~mm}$ each. The samples were mixed for $2 \mathrm{~h}$ at $37^{\circ} \mathrm{C}$ and stored thereafter at RT. Measuring temperature $77 \mathrm{~K}$.

\begin{tabular}{|c|c|c|c|c|c|c|}
\hline \multicolumn{2}{|l|}{ Reactants } & \multirow[t]{2}{*}{$\begin{array}{l}A_{*}^{2} \\
\pm 2 \text { Gauss }\end{array}$} & \multirow[t]{2}{*}{$\begin{array}{l}A_{1}^{3} \\
\pm 2 \text { Gauss }\end{array}$} & \multirow[t]{2}{*}{$\begin{array}{l}g^{2} \\
\pm 0.002\end{array}$} & \multirow[t]{2}{*}{$\begin{array}{l}g_{1}^{3} \\
\pm 0.002\end{array}$} & \multirow[t]{2}{*}{$\begin{array}{l}\lambda \\
{[\mathrm{nm}]}\end{array}$} \\
\hline & Time & & & & & \\
\hline Pepsin + EPP + Cu (II) & $2 \mathrm{~h} *$ & 157 & 173 & 2.291 & 2.245 & $625 \pm 3$ \\
\hline Pepsin +DAE + Cu (II) & $2 \mathrm{~h}$ & 157 & 172 & 2.291 & 2.245 & $650 \pm 3$ \\
\hline Pepsin + DAE + Cu (II) & 6 days & 157 & 174 & 2.290 & 2.245 & $650 \pm 3$ \\
\hline Pepsin + DAE + Cu(II) & 12 days & & 174 & & 2.245 & $640 \pm 3$ \\
\hline $\mathrm{Pepsin}+\mathrm{EPP}+\mathrm{DAE}+\mathrm{Cu}^{++}$ & $2 \mathrm{~h} *$ & 157 & 172 & 2.291 & 2.246 & $620 \pm 3$ \\
\hline
\end{tabular}

a EPP, 1,2-epoxy-phenoxypropane. b DAE, diazoacetyl-ethylester.

* Similar data were obtained for solutions stored 12 days at room temperature. 
pepsin with $\mathrm{Cu}(\mathrm{II})$. Addition of $\mathrm{Cu}$ (II) to a pepsinDAE solution leads to the formation of two complexes (Fig. 4B) with nearly identical magnetic parameters as have been obtained for the complexes II and III (Table II). This means that this inhibitor does not influence the complex formed between $\mathrm{Cu}(\mathrm{II})$ and pepsin. Again, complex III is the predominant one after several days (Fig. 4 D). A difference, however, is found for the absorption maximum of the d-d transition, which is located at about $640-650 \mathrm{~nm}$. The second absorption maximum at about $520 \mathrm{~nm}$, that was found, when complex II and III are in the solution, is no longer detectable.

According to the explanation given above and to the results obtained with peptides $[16,17]$, it is, therefore, assumed, that also in this ternary system a conformational change of pepsin occurs. The axial position of the $\mathrm{Cu}$ (II)-ion, however, is not occupied by a ligand belonging to pepsin.

The same results were obtained when $\mathrm{Cu}$ (II) reacted first with either pepsin or DAE and the corresponding third component was added thereafter. The complex between DAE and $\mathrm{Cu}(\mathrm{II})$, which can be detected in the ESR-spectrum $\left(\left|A_{\|}\right|=150 \mathrm{G}, g_{\|}\right.$ $=2.320$, spectrum not shown here) disappears after the addition of pepsin.

The second inhibitor used was EPP, which causes an esterification of Asp-32 of pepsin. Again, addition of $\mathrm{Cu}(\mathrm{II})$ to a pepsin-EPP solution results in the formation of complexes II and III (Fig. 4 A, Table II). A change of the ESR spectrum with time however, cannot be observed. The esterification of Asp-32 seems to hinder the conformational change of the enzyme.

The concomitant presence of both inhibitors, DAE and EPP, in a solution containing pepsin and

[1] K. C. S. Chen and J. Tang, J. Biol. Chem. 247, 2564 -2566 (1972).

[2] J. Tang, J. Biol. Chem. 246, 4510-4517 (1971).

[3] J. A. Hartsuck and J. Tang, J. Biol. Chem. 247, 2575 -2580 (1972).

[4] T. J. Rajagopalan, W. H. Stein, and S. Moore, J. Biol. Chem. 241, 4295-4297 (1966).

[5] R. S. Bayliss, J. R. Knowles, and G. B. Wybrandt, Biochem. J. 113, 377-386 (1969).

[6] J. S. Fruton, The Enzymes Vol. III, pp. 119-164, 3rd Edition (Ed. P. D. Boyer), Academic Press, New York and London 1971.

[7] G. R. Delpierre and J. S. Fruton, Proc. Natl. Acad. Sci. U.S. 56, $1817-1822$ (1966).

[8] E. Shaw, The Enzymes Vol. I, p. 118 (Ed. P. D. Boyer), Academic Press, New York and London 1970.

[9] R. L. Lundblad and W. H. Stein, J. Biol. Chem. 244, $154-160$ (1969).
$\mathrm{Cu}$ (II), leads to the same results as was obtained with EPP alone. The difference in the absorption maxima of $25 \mathrm{~nm}$ between the two complexes pep$\sin / \mathrm{EPP} / \mathrm{Cu}(\mathrm{II})$ and pepsin/DAE $/ \mathrm{Cu}$ (II) (Table II) may be due to a perturbation of the planar symmetry by different degrees of covalency of the ligand atoms.

In summary the following mechanism for the interaction between $\mathrm{Cu}(\mathrm{II})$ and pepsin in the presence of certain inhibitors might be suggested. $\mathrm{Cu}$ (II) forms a complex with DAE, which is no longer stable in the presence of pepsin. Thus, the faster inhibition of the enzyme activity caused by the inhibitor DAE does not seem to be due to a very active $\mathrm{Cu}$ (II)/DAE complex, as it was suggested by Lundblad and Stein. The faster inhibition of the enzyme activity, if $\mathrm{Cu}(\mathrm{II})$ is present together with an inhibitor, may be due to the fact, that the $\mathrm{Cu}$ (II)/DAE complex can reach the position of DAE attack in a shorter time. This is followed by an exchange of the DAE ligands of $\mathrm{Cu}$ (II) by pepsin ligands and then by the reaction of DAE with pepsin.

Pepsin exhibits a conformational change after forming a complex with $\mathrm{Cu}(\mathrm{II})$. Esterification of Asp-215 of pepsin by DAE also allows a conformational change, however, to a lesser extent. Such a conformational change is hindered by the esterification of Asp-32 by EPP. Since the ESR spectra of all the $\mathrm{Cu}$ (II)/pepsin complexes studied are almost identical, it might be concluded that $\mathrm{Cu}$ (II) does not coordinate with pepsin at the active center of the enzyme.

One of us (L.S.) thanks Euratom for a fellowship.

[10] W. H. Stein, Structure-Function Relationship of Proteolytic Enzymes (Eds. P. Desnuelle, H. Neurath, and M. Ottesen), Munksgaard, Copenhagen 1970.

[11] B. R. McGarvey, Transition Metal Chemistry, Vol. 3 (Ed. R. L. Calvin), pp. 89-201, Marcel Dekker, New York and London 1969.

[12] D. Kivelson and R. Neiman, J. Chem. Phys. 35, 149155 (1961).

[13] H. R. Gersmann and J. D. Swalen, J. Chem. Phys. 36, $3221-3233(1962)$

[14] H. C. Allen, M. I. Mandrioli, and J. W. Becker, J. Chem. Phys. 56, 997-999 (1972).

[15] L. Sportelli, H. Neubacher, and W. Lohmann, Rad. and Environm. Biophys. 13, 305-313 (1976).

[16] L. Sportelli, H. Neubacher, and W. Lohmann, Biophys. Struct. Mechanism. 3, 317-326 (1977).

[17] L. Sportelli, H. Neubacher, and W. Lohmann, Z. Naturforsch. 32 c, $643-646$ (1977). 